\title{
The Conceptual Architecture of Modified Emotions
}

\author{
Case: Typical Expressions of Care-emotions in the Art of the "Finnish Golden Period" in the Turn of 19th and 20th \\ Century
}

\author{
Tarkko Oksala ${ }^{1, *}$, Susanna Toivanen ${ }^{2}$, Aino Oksala ${ }^{3}$ \\ ${ }^{1}$ Department of Architecture, Aalto University, Finland \\ ${ }^{2}$ Department of Sociology, School of Health, Care and Social Welfare, Mälardalen University, Sweden \\ ${ }^{3}$ Stockholm University, Sweden
}

Copyright $(\mathrm{C} 2017$ by authors, all rights reserved. Authors agree that this article remains permanently open access under the terms of the Creative Commons Attribution License 4.0 International License

\begin{abstract}
The aim of this paper is to present conceptual architecture for modification of emotion. First the idea of emotion in general and as transformed to mean empathy and passion is considered. Secondly sympathy, compassion and feeling are discussed. This all is made in order to construct a firm basis to study emotions in general and their role in music, architecture and health care. A special attention is paid to using the stated ideas in interaction with migrants.
\end{abstract}

Keywords Architecture, Art, Care, Emotion, Therapy

\section{Introduction}

Emotions and rational cognition are indexes of the two-fold function of mind in the spectrum of other attitudes, like volition. Emotions are internal but they can be read in certain extent from outside. This challenging situation has created in our evolution certain modification of emotions, including:

- Emotion, empathy, en-passion

- Sympathy, compassion, feeling

The content of these notions is given under sub-paragraphs in relation to irrational cognition.

Irrational cognition was noted already by Plato and before that in Old China [1]. In Greece the word pathos was in use and is the base of derivations like empathy. Logos and pathos are unified in ethos. In mythos the function of pathos was related to law (nomos). These factors formed the transcendental part of universe over cosmos or micro-cosmos to be felt or known (Socrates [2], [3]).

Hermann Friedmann [4] has stated: "Der Kosmos erzeugt den Mann, der Mann erkennt den Kosmos".

Today the study of emotions is a central task in psychology [5], cognitive, value and social study [6], [7], [8]. Today we have to note also the role of emotion in cognitonics [9], [10], [11]. The basic cognitive study of emotion has many applications in medicine [12] and art theory $[13,14]$. In this paper we discuss the relation of emotion studies to therapy of refugees [15].

Emotions are important task in all art study including standard architecture. Here we use the term architecture also in allegory sense like "knowledge architecture". This means that the key concepts mentioned are organized architecturally.

\section{The Conceptual Architecture of Modified Emotions A}

\subsection{Emotion}

Human emotion is potentially named and directed type of aroused and intense feeling. It consists of ideas, like:

\section{- Named, directed, type \\ - Aroused, intense, feeling}

The potential naming refers to our habits to master our originally wild emotional nature with ratio (logos). Emotion is directed or better co-directed by somebody to something or somebody. This entity causes externally and then internally the emotion in question. Civilized emotions are thus types of feelings which we learn to classify.

Understanding emotions means that we know certain conditions in which they are aroused. Emotion is intense and significant so that we recognize and give a name to it. As mentioned the discussion of emotion is dependent on the open background set of feelings.

Music and architecture are archetypes of emotion transmission among arts [16], [17], [18]. Skills in emotion transmission are central in human communication and especially important in caring of somebody as personality. Humans are emotionally bound to their homes [11] and emigrants try to keep their central habits in function. 


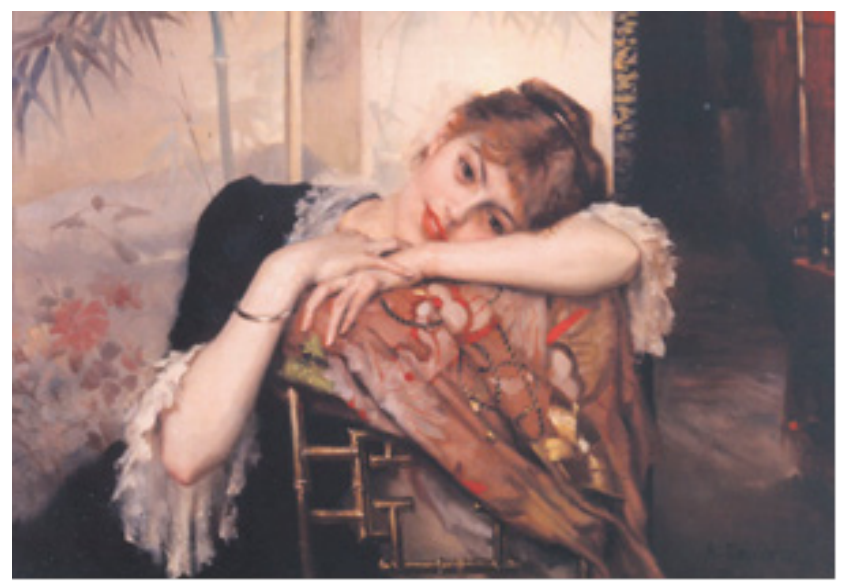

Figure 1A. Basic Emotions - Love (Virginie, Edelfelt 1883)

Case: The painting "Virginie" by Albert Edelfelt in Figure $1 \mathrm{~A}$ expresses the desire of forbidden love between the model and the artist. The painter has told according to documents that he works with love-hate and joy-sorrow in his four monumental works in advance. - Painting "Kullervo cursing" (Figure 1B) by Axel Gallén-Kallela is an early version to illustrate the famous epos Kalevala. Kullervo felt hate to his mother (in adoption) who baked stone into his bread.

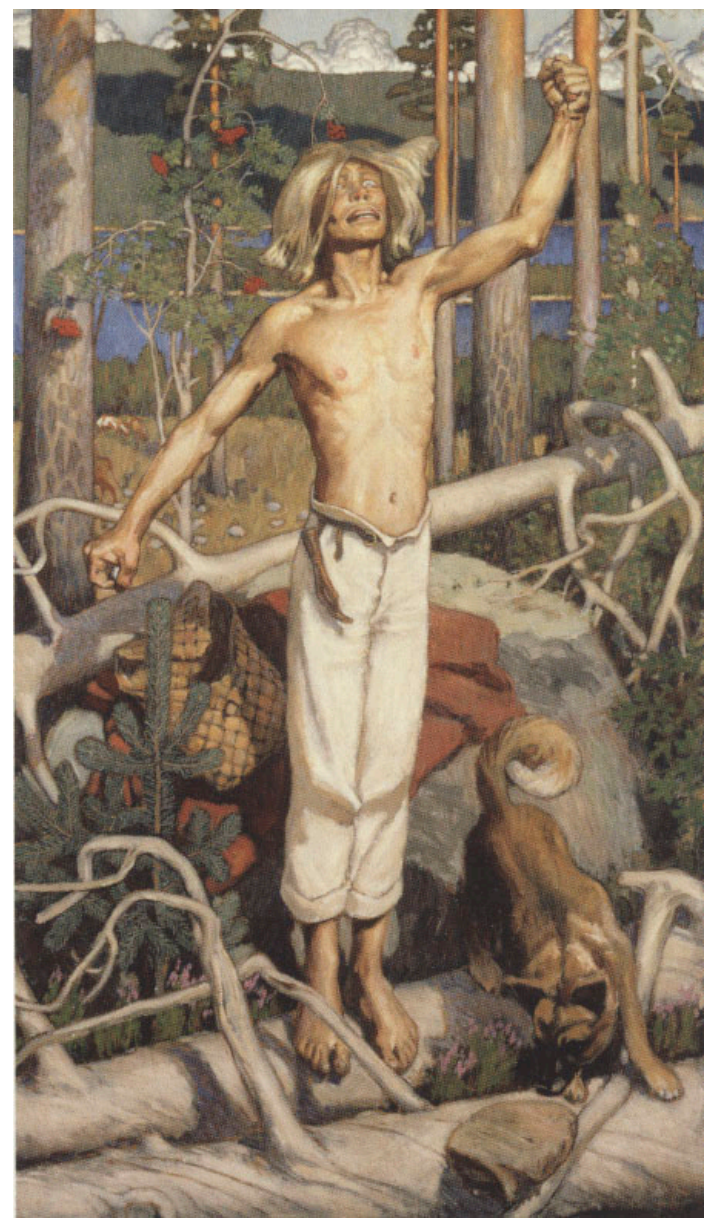

Figure 1B. Basic Emotios - Hate (Kullervo cursing, Gallén 1899)

\subsection{Empathy}

Empathy is an experience to understand emotional conditions of other persons from external perspective. Empathy locates (positions) other person's emotions in the emotion space which we have created. Empathy consists of: - Experience, understanding, other persons (mentality)

- Emotional, condition (arousal), external perspective

In the case of empathy we have to experience at the basic level that something is happening between two persons (or collective personalities). This act concerns understanding of other persons.

In empathy the concern is emotion. We should have certain ideas what conditions arouse the emotion in other person or collective personality [19]. Then it is possible to resist aggression for example. Because empathy concerns other person we have to understand the situation from at least some other perspective than our own.

The skill to position ourselves with others is the key to understand art or act well in caring about others. In this sense the home-district depends in a great extent on personal relations. If they are cut away traumatic experiences are born, which is a central problem in domestication.

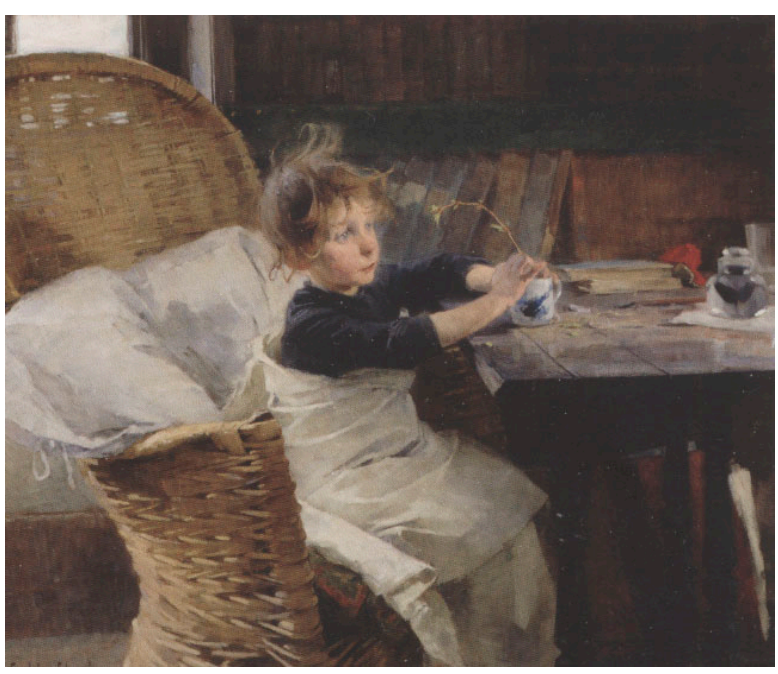

Figure 2A. Empathy (The Convalescent, Scherfbeck, 1888)

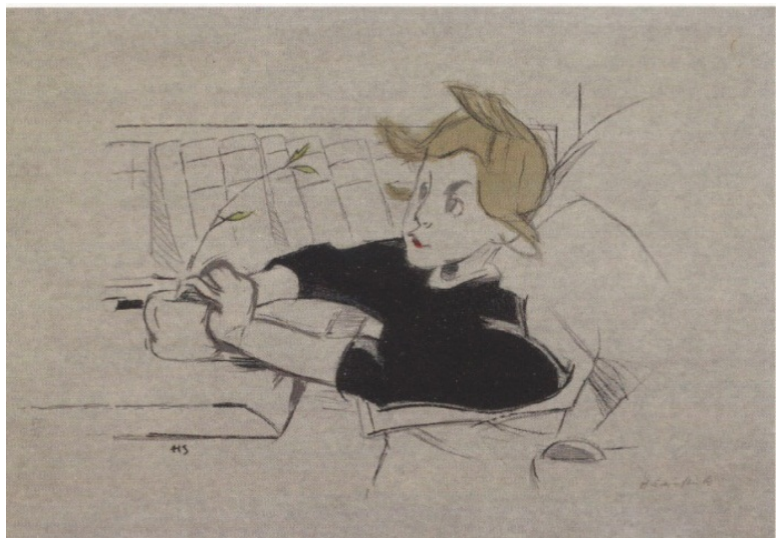

Figure 2B. Empathy (The Convalescent, Scherfbeck, 1938-39) 
Case: The two versions of the "Convalescent" (2A and 2B) by Helen Scherfbeck show empathy. We all know the situation from our own childhood. The second painting (2B) shows how feeling expression is saved under abstraction.

\subsection{En-passion}

Passion or better en-passion is a strong emotion which causes enthusiasm and the will to set goals. It has to be internalized fully and consists of:

- Strength, emotion, causation

- Enthusiasm, will, to set goals

Passion is strong in relation to the average emotion. It is related to motivation to do something, but also in the case of nearly impossible. Normal motivation concerns reasonable realization possibility and certain value to achieve.

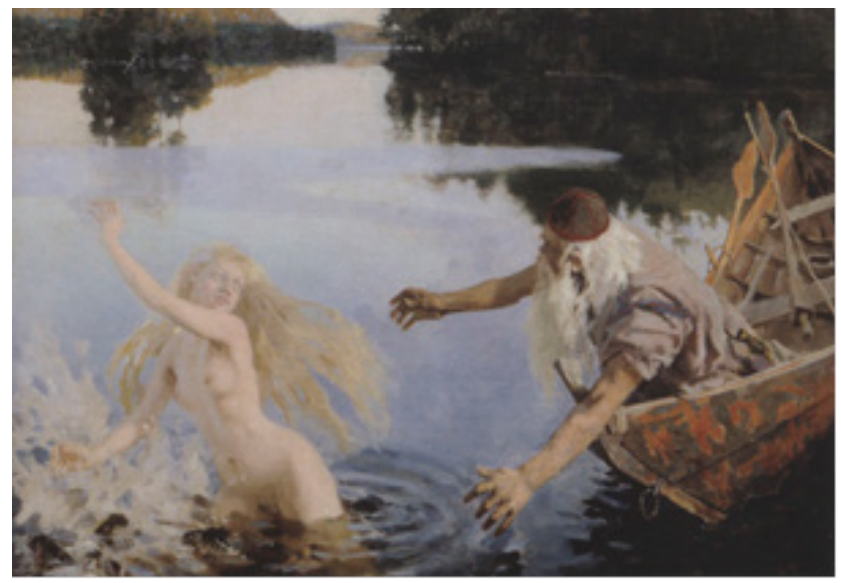

Figure 3. Passion (Aino Myth, Gallén, 1891)

Passion is connected to enthusiasm known in antique art theory (divine, irrational force). En-passion confirms our will and it is manifest in desires or utopias. En-passion refers to an internalized teleological commitment. Passion to quality is important in making high art [20].

The high ambition belongs to an extreme achievement in care (love of mother) and healing. The refugees have lost the dialogue with their original caring people. In therapy this all has to be won back in challenging situations.

Case: In another Kalevala painting (3) "Aino myth" Axel Gallén-Kallela expresses the natural passion toward beauty and youth in sexual terms.

\section{The Conceptual Architecture of Modified Emotions B}

\subsection{Sympathy}

Sympathy is a feeling to understand and share other person's emotional experience in an analogous perspective (than our own). Sympathy is the source of Concordia and it consists of:
- Feeling, to understand/share, other person's (mind)

- Emotional, experience, analogous perspective

Sympathy is more than only an experience and can be called a feeling deeply felt. Sympathy means not only the understanding but also the sharing of common aspirations. Its idea is to recognize something similar in others than we feel in ourselves.

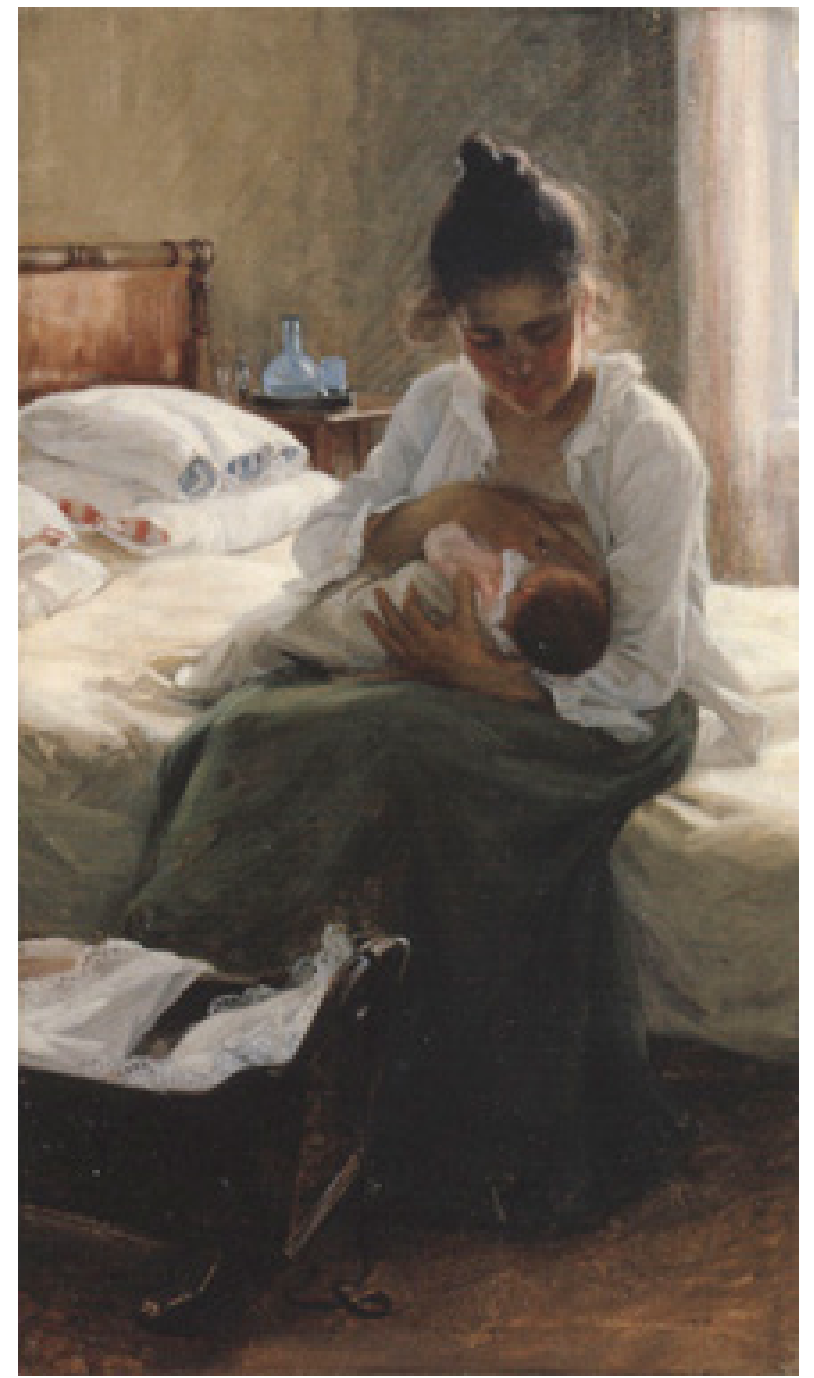

Figure 4. Sympathy (Mother, Danielson-Gambogi, 1893)

Sympathy concerns feelings at an emotional and experienced level and in the sympathy the perspectives are typically shared. This is also manifest at the division of material utilities (altruism) [6].

In higher spiritual life sympathy may be extended to the direction of empathy which means that we then also sympathize with different persons besides ourselves. It is of course possible to hate ourselves, but this is another problem. In therapy the patient has to get free of hate and meet sympathy in a new life situation.

Case: "Mother" or better Child and Mother is the most classical theme manifesting sympathy (> Madonna). This is expressed in Figure 4 by Elin Danielson-Cambogi. 


\subsection{Compassion}

Compassion is emotion and concrete feeling as response to joy or suffering (of others) which motivates to help others. It orientates us in societal life and consists of:

- Emotion, feeling, response

- Suffering/ joy of others, motivation, helping

Compassion should normally be on the level of emotion but it can achieve the status of (en) passion. It would also be a concrete feeling in a certain agent capable of responding.

Ethical agents react to suffering of others in a pan-ethical sense - to avoid suffering. This motivates a mentally healthy person to consider the realization possibilities to help. As some wise persons have stated the goal of life is to help others. [7]

Refugees have often suffered in extreme conditions and a certain amount of compassion is welcome in the therapy.

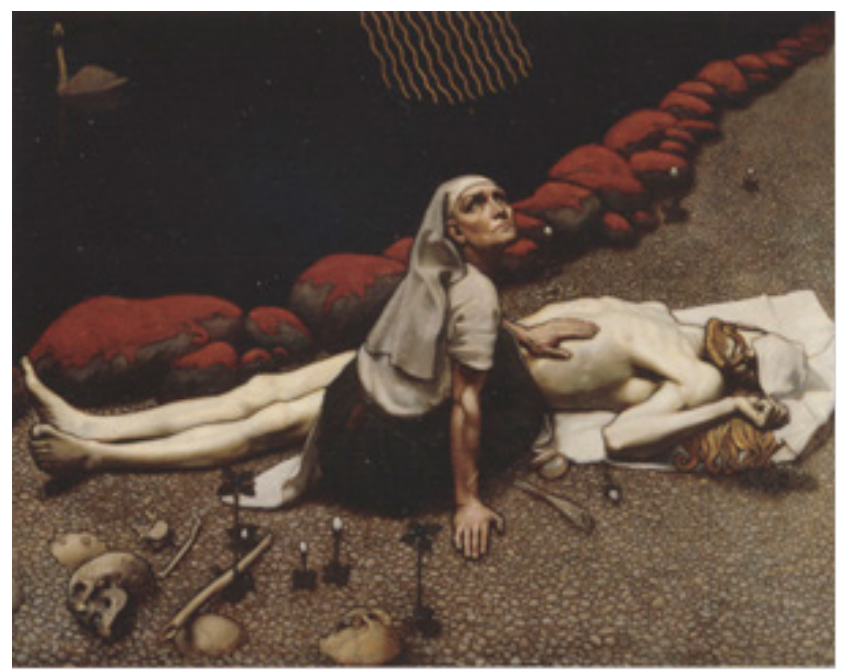

Figure 5. Compassion (Lemminkäinen's Mother, Gallén, 1897)

Case: Third Kalevala Painting by Axel Gallén-Kallela in our series illustrates the feeling of a mother after losing her son. The work (5) has name "Mother of Lemminkäinen". Compassion here is mixed to the hope to get the son back into life. - The picture symbolizes for us also the hard destiny of so many refugees from war districts of today.

\subsection{Feeling}

Feeling is a private individual experience which has a potential subjective emotional representation. Feeling is connected to living persons and it is open to new realizations. It consists of ideas, like:

- Private, individual, experience

- Subjective, emotional, representation

Feeling is internally private and is realized in an individual experience.

Feelings are subjective emotions, which may get a name when recognized. Then we have the representation of them in mind or (potentially) in language. The field of feelings is a part of creative life and we may give names to new emotions born. The field of emotions is already rich and typical examples (sadness, hate, apathy; self-confidence, love, joy) are only the most typical. [6]

In concrete therapy it is important that the register of various feelings will be balanced. Then a certain amount of both love but also the justified hate normalizes the situation.

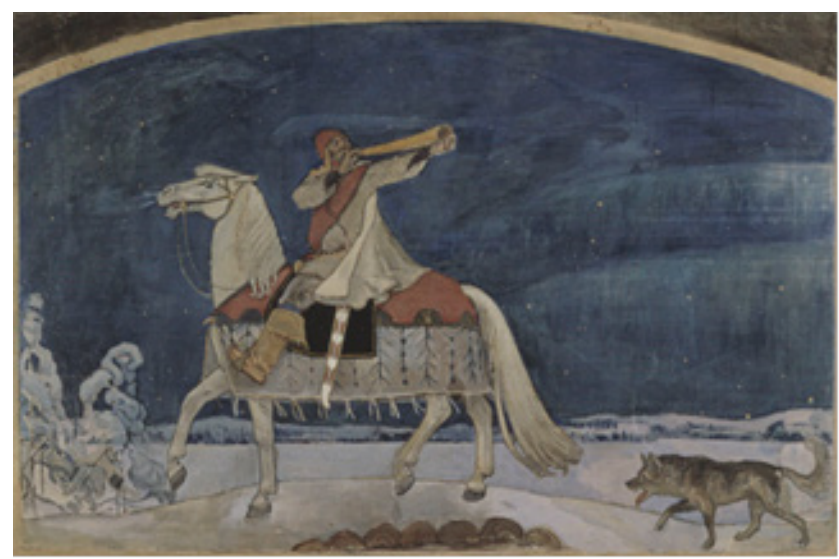

Figure 6. Dark feelings of war and cold atmosphere (Kullervo sets off to Battle, Gallén, 1901)

Case: Hate (1B) depicted earlier is related to omnipotence in Kalevala painting by Axel Gallén-Kallela. The hate experienced led in the story finally to war act. The name of the painting (6) is "Kullervo sets off to Battle". The feeling in this painting is extremely cold.

\section{Methods and Results}

The method is conceptual analysis in order to define categories of emotions that are tested by usages from art production. Successful definitions create facilities for theory to describe and explain or predict reality. In our case the reality is mental and manifested in the body and facial or voice expression of migrants.

The study shows how art and especially art that depicts human interaction in care, can be evaluated and understood using the conceptual frame developed. These aspects are central in humanities in addition to the basic tasks of theory known from science (above). It is also evident that both production of art and productive action in care work can be discussed using these terms. To read emotions is our natural talent, but it can be boosted with exercise, dialogue and communication.

\subsection{Literature Research and Study}

The study discussed concentrates to the definition of emotion-related phenomena in harmony with everyday language and various theories. This is important because there is a lack of consensus in definitions. The well-known 
ideas, that emotions are intense feelings and that feelings are subjective representations of emotions, are in coherence with our characterizations. Basic emotions are classified in literature in many ways as abstract typologies (pleasant, unpleasant; active, deactive) or by giving direct type-names [5].

The study of basic emotions has long a history [22] and large spectrum of results. The lack of consensus of definition is clearer in the field of applied social emotions like empathy, passion, sympathy and compassion. The study of these forms has become also active $[23,24,25,26]$. One central tool to learn about emotions is literature study or reading of text in general [27]. To read fiction is also helpful, because it is expected that emotion transmission in it is believable.

\subsection{Empirical study}

Emotions are studied in relation to basic categories of science from chemistry to anthropology. Central fields include psychology and sociology. Among them we have the problem to study emotions in empirically reliable and valid ways. We have types of emotion study like [28] [29]:

- Statistical, empirical, logical (emotion) study

- Comparative, qualitative, quantitative (emotion) study

Behavioral interpretation of emotions [22] gives good basis to use statistical methods. Statistical emotion study in trans-modern sense may be made in laboratories starting from brain study or with the aid of language by making statistics of words and expression like in the case of poetry. Real empirical study has to note the difference of extensive vs. intensive. We can use questionnaires to get emotional information as in the case of a value study [30]. Such studies should be based on protocol design and logical analyses or conceptual frames can be utilized. This paper offers one alternative.

In the case of emotions we compare them in our internal world or as based on communication. Emotions are for us first of all qualitative. They either exists or not [20]. The idea of intensiveness means that in science it is meaningful to aim at measuring the amount of emotion. [31] A good example is the measurement of emotion related to aesthetic value (order/ complexity and surprise) [32].

This paper aims at facilitating methods of empirical study in order to prepare, plan and design experiments on various application fields. Scientific study of emotion is the base for applications. On the other hand we have to note studio work in art as well as care practice in expression, emotion reading and reacting. In art work it is for example to compare the emotional effect of works in similarity, contrast or as scaled. This is typical inside some category of art works, but it is also possible to compare emotional effect between categories like abstract painting and functionalistic architecture or between pop art and post-modern architecture. In perceptional level of cognition such phenomena are studied under syn-aesthesia for example in the case how to translate visual art to music etc.

\subsection{Applications}

The idea to create a general socially relevant frame for emotion and feeling studies has both theoretical and educational relevance. It is important to have common frame (this or an alternative) to share. The field of applications is large and we concentrate on art and "care art" (skill).

In art theory it is evident that love is one central emotion to be expressed. In theoretical frames such everyday concepts are replaced often by theoretical (statistico-typological) dimensions. Basic emotions and feelings are often mentioned inside the names of art works. In addition to that complex social emotions are themes to be found without clear names in art. This holds true for the whole spectrum of basic arts like architecture, sculpture, painting, music, dance or poetry but holds for complex arts like opera, ballet and drama. A good test-bench is of course poetry to find key words of emotions felt intensively (e.g. Mueller). In performing arts it is possible to utilize brain study for example in the experience flows in Cinema. In architecture experience is multi-modal and connected to movement and the preparation of experiments is however challenging.

Analysis of emotions in general and in art serves of course subjective poetic skills (fabrication) [20]) but especially art education [33]. In art theory the role of emotions is largely pointed out [17].

Art means both fine arts cultivating emotional expression but also skills in general. In care education the reading of emotions and feelings from patient's body language [34] is a basic skill. In addition to that the understanding of complex social emotions (empathy...) is a target of various seminars. Works of art offer good reference material in education before using photos and other simulation tools. In fact the idea to read emotions is central task in AI [35] and its critique [13]. Applications of emotion basics and modified emotion theory lead to many emergent combinations. One good example is art therapy as part of emotion based therapy in general.

\section{Discussion}

\subsection{Intuition, Imagination and Inspiration in Care and Therapy}

Emotion is connected to the subconscious and only a few persons have a rational access there. It is also typical that we have access to the subconscious temporally before falling asleep, in sleep or just after waking up. The mode of thinking which connects us to our own or others' emotions is intuition. Intuition has its basis in imagination. For example Swedenborg saw the burning of Stockholm probably by intuition in a vision, which gave a lot of thinking to Kant. To understand achievements of nature or culture by intuition may give us inspirations. They can be worked further in semi-rational writing but also in a more intuitively 
transmitted imagination in visual art. Also these modes of art have a common link "ut pictura poesis" as Horace has stated. What humans have learned during evolution about emotion via intuition is recorded in memory in the form of tacit knowledge [36]. In the art of therapy we need creative skills [11] in order to understand the individual problems depending on case. On the other hand art is a good reflective tool in therapy.

Art is "aesthetic, evidently given representation of emotional experience in a concrete artwork" [14], which idea explains the importance of feeling transmission in true art $[17,37]$. Art is also an important tool to be applied in therapy, care ethics [38] or in peace politics in general [39].

Nowadays psychological medication has become a more usual treatment form instead of more expensive therapy forms. Also the therapeutic alliance between the patient and the therapist has been partly forgotten. This has happened, when the evidence-based practice has conquered the psychological sector (and separated it from traditional psychiatry). New models of care are born all the time but the effect might not be the same when other personnel are working with the invented model. What is important is the influence of the person that invented the way of therapy that worked for the patients and not the actual habit of care in itself. This should be studied more in the future in health care $[40,41]$.

Art therapy is a well-known tool of domestication. Our examples from a high period of professional art show how much our feelings concern patients violated in the sense of suffering. The other pole is a happy life showing the direction into which other persons and patients should be advised. The task of life is to help other living beings.

\subsection{Care of Trauma in Forced Migration}

Forced migration due to wars and crises can be viewed as a stressful and exaggerated developing process of separation [42]. The stress rising from such a migration process can be associated with pre-migration, migration, and post-migration experiences. For instance, the circumstances in the country of origin from where the refugees are fleeing, the dangers of the migration journey itself, and the conditions in the country of destination where cultural transition could lead to isolation and disconnection from the host society. Cultural transition is influenced by many factors, for instance the Forced migration due to wars and crises can be viewed as a stressful and exaggerated developing process of separation goals of migration and how they are realized, whether there is access to support systems such as health care, labor market counselling and social welfare. Also, changes in lifestyle and difficulties learning a new language add to the hassles of daily life. Moreover, comparability of present education and the possibility to get re-education are central aspects in adaptation process to a new context. Many refugees have been exposed to different degrees of torture and war trauma, and getting a footing on the labor market may therefore be a long process and in some cases even impossible. To summarize, cultural transition is about harmony or conflict between the cultures of refugees' countries of origin and destination [42].

\subsection{Art Therapy and Migrants}

Being a refugee is a vulnerable position in society often associated with increased risk of depression, anxiety and feelings of hopelessness connected partly to identity loss. Previous research shows that art therapy was beneficial in facilitating adjustment and integration of immigrant children experiencing such difficulties [43]. The children were able to bridge cultural and language barriers between themselves and the therapist through the symbolic communication of their experience trough art [43]. Thus, art therapy may facilitate the integration of refugees' cultural identity and their self-concept during times of distress. Art therapy may therefore be a more efficient method for integration compared to traditional psychotherapy which needs to be adapted to minority populations in order to be supportive [42]. Creative art therapies provide a non-verbal method which is more appropriate than psychotherapies where language is the main means of communication. Art therapy with a cultural focus enables refugees to recreate a sense of coherence and meaningfulness in their present exile situation, and thus strengthens the ability to better cope with the transition period, to face and overcome challenges encountered in the new country.

\section{Conclusions}

We have shown how modifications of emotion are decisive factors in fine arts but also in the art of healing and therapy. Emotions are recorded mainly in tacit knowledge and the skill of therapist depends both on natural talent and well internalized education. The idea to create a conceptual frame for emotion-based works like art or care needs as a counter force criticality. The conceptual frames and categories were tested in relation to suggestions in literature and cognitonics. Definitions and the preference of basic constituents in emotion discussion differ and to speak about consensus is not fair. Both literature and studies in cognitonics give support to our frame, which can be of course developed to serve practical challenges of many kinds. In this sense the factual test-bench of our frame is developing emotions study in general and its application to complex societal emotions (discussed) especially as used in art therapy.

\section{Acknowledgements}

This paper is based on discussions with Joel Majurinen and Jyrki Tyrkkö. The publication is an extended version of 
[44] presented in Information Society 2015 under Gognit-2015, which opportunity is also gratefully acknowledged. The figures used as examples are included in the collections of Art Museum of Joensuu (Figure 1A) and National Art Museum of Finland (ATENEUM) (Figures 1B-6) and we thank for the possibility to publish them in this connection.

Figure 1A. Albert Edelfelt, Virginie, 1883, Arla Sederberg Collections, Photo: Art Museum of Joensuu

Figure 1B. Axel Gallén-Kallela (originally Axel Gallén, later Akseli Gallen-Kallela), 1899, Kullervo Cursing, Finnish National Gallery, Photo: Jukka Romu

Figure 2A. Helene Scherfbeck, The Convalescent, 1888, Finnish National Gallery, Photo: Yehia Eweis

Figure 2B. Helene, The Convalescent, 1938-39, Antell Collections, Finnish National Gallery, Photo: Hannu Aaltonen

Figure 3. Axel Gallén-Kallela, 1891, Aino Myth, triptych (middle) Finnish National Gallery, Photo: Hannu Aaltonen

Figure 4. Elin Danielson-Gambogi, 1893, Mother, Finnish National Gallery, Photo: Antti Kuivalainen

Figure 5. Axel Gallén-Kallela, Lemminkäinen's Mother, Antell Collections, Finnish National Gallery,

Photo: Jouko Könonen

Figure 6. Axel Gallén-Kallela, 1901, Kullervo Setts of to Battle, Finnish National Gallery, Photo: Jukka Romu

\section{REFERENCES}

[1] O. B. Duane. Feng-Shui, ICOREC, pp. 44, 54. 1997

[2] T. K. Oksala. Homeroksesta Alvar Aaltoon (From Homer to Alvar Aalto), W+G, p. 18. 1986

[3] I. Niiniluoto, P. Stenman. Minä (The Self), Suomen Filosofinen Yhdistys, p. 5. 1988

[4] H. Friedmann. Die Welt der Formen, Beck. 1925/30

[5] P. Ekman. An argument for basic emotion, in Cognition \& Emotion 6, pp. 169-200. 1999

[6] D. O. Hebb. Psykologia (Psychology), Tammi, pp. -, 298, 283. 1975

[7] M. Puohiniemi. Arvot, asenteet ja ajankuva (Values, attitudes and the time), Limor, pp.-, 159. 2002

[8] G. E. Lasker. Sociodiagnostic Methodology: Theory and Applications, in G. E. Lasker and R. Bahboud (eds.) Socio-diagnostics and Socio-mapping, IIAS, p. 31. 2012

[9] V. A. Fomichov, O. S. Fomichova. A map of Cognitive Transformations Realized for Early Socialization of Children in the Internet Age, in M. Bohanec et al (eds.) Information Society 2011, Ljubljana, pp. 353-35, 353. 2011

[10] T. Oksala, A. Oksala. Cognitonics Studying the Skills of Mind, in M. Bohanec et al (eds.) Information Society, Ljubjana, pp. 408-410. 2011
[11] T. Oksala, A. Oksala. The Architecture of Personality and Personal Development, in e-proceedings of Information Society 2013 (Ljubljana). 2013

[12] R. Schleifer. Practical Reasoning and Practical Humanities Working with Medicine, in M. Bohaned et al (eds.) Information Society 2011, pp. 363-367. 2011

[13] O. S. Fomichova and V. A. Fomichov. Impressionism in the Mirror of Cognitonics, in M. Bohaned et al (eds.) Information Society 2011, Ljubljana, pp. 380-383, 380. 2011

[14] T. Oksala. Varieties of Emotions in Art, in G. E. Lasker, H. Schinzel and K. Boullard (eds.), Proceedings of Inter-Symp 2015 (Art \& Science), Baden-Baden, pp. 53-58. 2015

[15] A. Oksala. Socialsekreterares tankar kring trauma i deras arbete där de bemöter flyktningars, Forskningsplan, (Thoughts of Social Secretary around Trauma in their work when they meet emigrants, (Research Plan), Stockholms Universitet, 2012

[16] P. Bekker. Organische und Mechanische Musik, Stuttgart, p. 9. 1928

[17] S. K. Langer. Feeling and Form, Routledge. 1953

[18] C. Van de Ven. Space in Architecture, van Gorcum, p. 67. 1980

[19] E. Kaila. Persoonallisuus (Personality), Otava. 1946

[20] A. Aalto. Luonnoksia (Sketches), Otava. 1972

[21] R. Plutchik. Nature of emotions, American Scientist 89 (4):349. 2002

[22] W. James. What Is an Emotion? Mind. 9 (34), 188-205. 1884

[23] R. Solomon. The Passions: Emotions and the Meaning of Life, Hackett Publishing. 1993

[24] Th. Dixon. From passions to emotions: the creation of secular psychological category. Cambridge University Press. 2003

[25] E. Harmon-Jones, K. Vaughn-Scott, S. Mohr, J. Sigelman, C. Harmon-Jones. The effect of manipulated sympathy and anger on left and right frontal cortical activity. Emotion. 4, pp. 95-101. 2004

[26] S. G. Chapman. The five keys to Mindful communication, Shamhala. p. 70.2012

[27] P. C. Hogan. What Literature Teaches Us about Emotion? Cambridge University Press. 2011

[28] T. Oksala, S. Toivanen. Architectural Sociology, Art or Science, in G. E. Lasker et al (eds.), Proceedings of Inter-Symp 2016 (Art \& Science), Baden-Baden, pp. 41-46. $2016 \mathrm{a}$

[29] T. Oksala, S. Toivanen. (2016 b): Sociology meets architecture, in G. E. Lasker, K. Hiwaki (eds.), Proceedings of Inter-Symp 2015 (Sustainable Development and Global Community 2016), Baden-Baden, pp. 41-46. 2016 b

[30] Sh. H. Schwartz. Kulttuuriset arvo-orientaatiot; Kansallisten erojen luonne ja seuraukset (Cultural Value Orientations: Nature \& Implications of National Differences), trans. M. 
Puohiniemi, Limor kustannus. p. 7. 2011

[31] K. R. Scherer. What are emotions? And how can they be measured? Social Science Information. 44 (4), 693-727. 2005

[32] P. F. Smith. Architecture and the Human Dimension, Godwin, pp 59-61. 1979

[33] L. - O. Routila. Taidekasvatuksen tieteenala (The Science of Art Education), Clarion, p. 15. 1985

[34] Ch. Darwin. The Expression of Emotion in Man and Animals, London. 1872

[35] I. Niiniluoto. Äly, tahto, tunne ja tekoäly (Intelligence, will, emotion and AI) in I. Niiniluoto, Maailma, minä ja kulttuuri, Otava, pp. 122-139. 1990

[36] M. Polanyi. The Tacit Dimension, Chicago. 1966

[37] H. Schinzel. King Kong is too small, in G. E. Lasker, H. Schinzel and K. Boullart (eds.), Proceedings of Inter-Symp 2015 (Art \& Science), Baden-Baden, pp. 41-46. 2015

[38] H. Stoltenberg-Lerche. Cartoons, Compassion, Care and Chouchair: Art and Political Ethics in Times of Terrorisms, in G. E. Lasker, H. Schinzel and K. Boullart (eds.), Proceedings of Inter-Symp 2015 (Art \& Science), Baden-Baden , pp. 65-75.
2015

[39] K. Boullart. Art and the Politics of Peace: An Ambivalent Relationship, in G. E. Lasker, H. Schinzel and K. Boullart (eds.), Proceedings of Inter-Symp 2015 (Art \& Science), Baden-Baden, pp. 77-81. 2015

[40] S. Toivanen. Work-Related Inequalities in Health, Health Equity Studies No 9. 2007

[41] T. Toivanen, S. Toivanen. Utsatt för tortyr. At möta och rehabilitera traumatiserade flyktingar (Exposed of torture. To meet and rehabilitate traumatized refugees), Gothia. 2014

[42] Y. M. Lemzoudi. Migration: Acculturation process, cultural identity development, and art therapy imagery of adolescent migrants. Canadian Art Therapy Association Journal, 20(2), 2-21. 20007

[43] T. Sit, T. Facilitating Adjustment in a New Cultural Setting: Based on a workshop presented on March 30, 1996 at Wilfrid Laurier University. Canadian Art Therapy Association Journal, 10(2), 69-76. 1966

[44] T. Oksala, A. Oksala. The Conceptual Architecture of Modified Emotion, in e-Proceedings of Information Society (IS 2015) - Cognit-2015. 2015 